\title{
Age-related Responses of Serum Testosterone to Human Chorionic Gonadotropin in the Stallion
}

\author{
Kiyoshi Okuda*, Chikako Ishimoto, Hideo Ohishi ${ }^{1)}$, Norihisa Maekawa ${ }^{2)}$, and Kunitada Sato \\ School of Veterinary Medicine, Obihiro University of Agriculture and Veterinary Medicine, Obihiro, Hokkaido O80, \\ ${ }^{1)}$ Agriculture Mutual Aid Association of Hidaka District, Mitsuishi, Hokkaido 059-31, \\ ${ }^{2)}$ Practitioner, Mitsuishi, Hokkaido 059-32, Japan
}

(Accepted for publication August 28, 1990)

\begin{abstract}
Summary. The response of serum testosterone to human chorionic gonadotropin (hCG, $10000 \mathrm{IU}$ ) given as a single intra-muscular injection was evaluated in middle age $(n=3 ; 8,9$ and 10 years old) and old $(\mathrm{n}=2 ; 19$ and 25 years old) stallions in nonbreeding (September) season. A sharp rise of testosterone after $2 \mathrm{hr}$ was observed only in middle age stallions, but not in old stallions. However, 48 72 hr after hCG administration, a clear and sharp increase was demonstrated in all stallions regardless of age. The different response of serum testosterone to hCG according to age should prompt a reevaluation for understanding of endocrine function of horse testis using this agent. KEY WORDS: STALLION OF OLD, AGE, TESTOSTERONE BY HCG.
\end{abstract}

Jpn J Anim Reprod 37, 21-25, 1991

Testicular Leydig cell-reserve capacity or the presence of testicular tissue can be estimated by the testosterone response to the administration of hCG in man (Saez and Forest, 1979), bull (Sundby and Farahat, 1978), ram (Garnier and Saez, 1980) and stallion (Cox et al., 1973, Silberzahn et al., 1988). The kinetics of horse testicular responsiveness to hCG stimulation has hitherto been used mostly as the diagnostic blood test for cryptorchism during short periods of time up to $2 \mathrm{hr}$ (Cox, 1989). The biphasic testosterone response to the administration of hCG has been observed in several species (man: Saez and Forest, 1979; Padron et al., 1980; bull: Sundby and Farahat, 1978; ram: Garnier and Saez, 1980), yet it has not been reported clearly in the stallion.

The present experiment was designed to study the short and long term effect of hCG

\footnotetext{
* Reprint requests to Dr. K. Okuda, whose present address is Division of Animal Science, Faculty of Agriculture, Okayama University, Okayama 700, Japan.
}

on serum testosterone response to hCG between middle age and old stallions, and therefore to provide a better understanding of the endocrine function of the horse testis.

\section{Materials and Methods}

\section{Animals}

Six healthy stallions, 2 Anglo Arab (9 and 18 year-old) and 4 Thoroughbred (8, 10, 19 and 25 year-old), from a stallion-center were divided into the 2 groups according to age (Table 1): All stallions were housed in individual stalls, fed oats and had access to open pastures and water. They were exposed to natural lighting and ambient temperatures.

\section{Experiment}

These experiments were carried out in Japan at about $42^{\circ}$ N.L. in nonbreeding (September) season of mares. A week before hCG administration, blood samples from each stallion were collected from the jugular 
Table 1. Breed and age of stallions used in the experiment

\begin{tabular}{cccc}
\hline Group & No. & Breed & Age \\
\hline \multirow{2}{*}{ Middle age stallions } & 2. & Anglo Arab & 9 \\
& 3. & Thoroughbred & 8 \\
& & & \\
& 4. & Anglo Arab & 18 \\
Old stallions & 5. & Thoroughbred & 19 \\
& 6. & Thoroughbred & 25 \\
\hline
\end{tabular}

vein every $3 \mathrm{hr}$ for $18 \mathrm{hr}$ starting at 8 a.m. One week later, all stallions except No. 4 received a single intra-muscular injection of 10000 IU hCG (Gonatropin: Teikoku Hormone Mfg. Co., Tokyo, Japan) at 8 a.m.

Blood samples were drawn before, and 1 , 2, 3, 6, 9, 12 and $24 \mathrm{hr}$ after hCG injection, and then once a day from the 2nd to the 6 th day at 8 a.m. Blood serum was separated immediately after blood collection by centrifugation and stored at $-20^{\circ} \mathrm{C}$ until testosterone analysis.

\section{Assay}

Serum concentration of testosterone was analysed in duplicate by radioimmunoassay. The anti-testosterone serum (JK-31) was obtained from Teikoku Zoki Pharmaceutical Co., Tokyo, Japan, and the cross-reactivity with other steroids was as determined by Makino (1973). Serum $(50 \sim 200 \mu \mathrm{l})$ was extracted with $2 \mathrm{ml}$ diethyl ether and the ether extract was assayed for testosterone without chromatography. Mean recovery after extraction of $\left[{ }^{3} \mathrm{H}\right]$ testosterone added to the pooled serum was $90 \%$. Free and bound ligands were separated by dextrancoated charcoal after $1 \sim 2 \mathrm{hr}$ incubation at $4^{\circ} \mathrm{C}$ with labelled steroid and the antiserum. The limit of detection was $0.02 \mathrm{ng} /$ tube. The intra- and inter-assay coefficients of variation based on 10 replicates were $5.9 \%$ and $12.9 \%$, respectively. To avoid interassay variation, all serum samples from a single animal were measured in the same assay.

\section{Statistic}

The data in diurnal changes of testosterone levels were analysed by one-way analysis of variance, and Tukey-test was performed to determine significant differences between means.

\section{Results}

\section{Diurnal variations of serum testosterone}

In the middle age stallions, there were no significant differences between the highest and the lowest serum testosterone concentrations from samples collected at $3 \mathrm{hr}$ intervals through a period of $18 \mathrm{hr}$. Howev$\mathrm{er}$, in the old stallions, significant differences were confirmed between the mean levels of serum testosterone at different times. There were no significant differences in the serum testosterone levels at the same time between the middle age and old stallions, although marked variations were observed between stallions at any given time (Fig. 1). They showed peaks at $14: 00(1.41 \pm 0.38 \mathrm{ng} / \mathrm{ml})$ in middle age stallions and at 17:00 (0.91 \pm 0.12 $\mathrm{ng} / \mathrm{ml}$ ) in old stallions, and showed the lowest levels at 5:00 $(0.49 \pm 0.16 \mathrm{ng} / \mathrm{ml})$ in middle age stallions and at 8:00 $(0.39 \pm 0.06$ $\mathrm{ng} / \mathrm{ml}$ ) in old stallions.

\section{Response to hCG stimulation}

The serum testosterone levels of all 3 middle age stallions showed 2 marked peaks (Fig. 2a), whereas in the old stallions only one peak was registered (Fig. 2b). In the middle age stallions, the concentrations increased $2 \mathrm{hr}$ after hCG injection, then remained constant for $7 \mathrm{hr}$ and decreased gradually until $24 \mathrm{hr}$ after injection. Thereafter, they increased again sharply and showed the next peak at $72 \mathrm{hr}$. But the concentrations in the 2 old stallions increased only slightly until $24 \mathrm{hr}$ after injection, and thereafter showed peaks at $72 \mathrm{hr}$. The quantitative responses at $72 \mathrm{hr}$ after injection in each stallion were 6.4 fold (Horse No. 1), 9.8 fold (No. 2) and 22.5 fold (No. 3) in the middle age stallions, 5.4 fold 


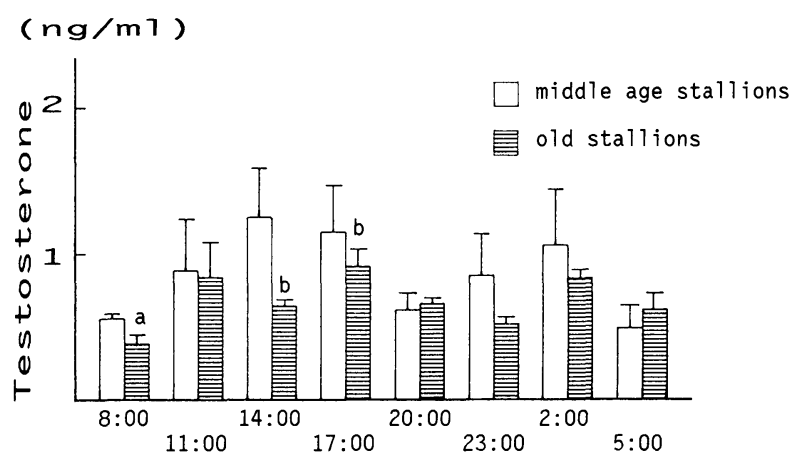

Fig. 1. Mean serum testosterone concentrations at different times of the day. Blood samples were collected every $3 \mathrm{hr}$ for $18 \mathrm{hr}$ starting at 8 a.m. The vertical lines indicate + standard error. Significant differences; $a-b, P<0.05$.

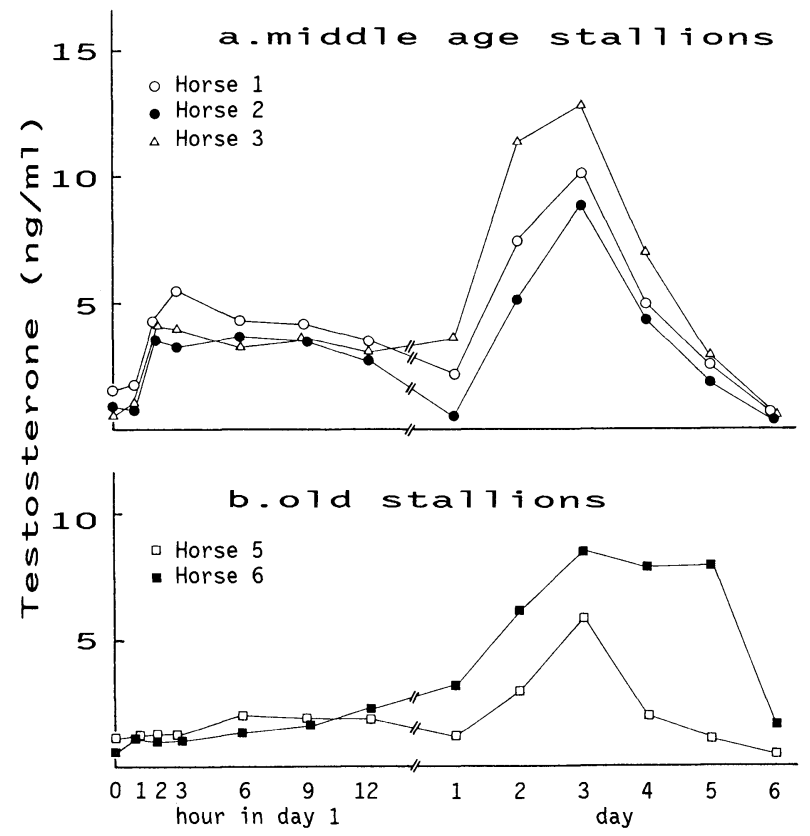

Fig. 2. Serum concentrations of testosterone after a single intramuscular injection of hCG (10000 IU) in middle age (a) and old (b) stallions. Blood samples were taken before, and 1, 2, 3, 6, 9, 12 and $24 \mathrm{hr}$ after hCG injection, and then once a day at 8 a.m.

(No. 5) and 14.3 fold (No. 6) in the old stallions, as much as the levels before hCG injection.

Testosterone concentrations returned to the basal levels about 6 days after hCG injection both in the middle age and old stallions.

\section{Discussion}

There are several reports about diurnal changes of testosterone concentrations in blood of stallions. Some reports show that concentrations of testosterone were highest during early morning and lowest during 
early or late evening (Sharma, 1976; Kirkpatrick et al., 1976). On the other hand, Thompson et al. (1985) observed high levels of testosterone during the late morning and early afternoon. Our results were in agreement with those of Thompson et al. (1985). These conflicting results concerning the diurnal may be due to the anticipation of sexual activity at different times of the day (Graham and Desjardins, 1980; Thompson et al., 1985) depending on surroundings. As, in any case, serum testosterone profiles after hCG administration appeared to be independent of diurnal rhythms in all intact stallions regardless of age, we considered that the responsiveness to hCG could be discussed regardless of diurnal changes in serum testosterone.

Cox et al. (1973) who administrated 12000 IU hCG in the jugular vein and took blood plasma samples every $30 \mathrm{~min}$, have reported that testosterone concentrations increased within $30 \mathrm{~min}$ of the injection and that testosterone returned to basal level $2 \mathrm{hr}$ after injection. In the present study, serum testosterone increased $2 \mathrm{hr}$ and then decreased gradually until $24 \mathrm{hr}$ after intra-muscular injection of 10000 IU in middle age stallions. It seems that this delayed response of testosterone might be caused by the different methods of hCG administration.

A biphasic plasma testosterone response was observed by the administration of hCG to man (Saez and Forest, 1979; Padron et al., 1980), bull (Sundby and Farahat, 1978) ram (Garnier and Saez, 1980). In this study, clear biphasic testosterone responses were observed in middle age stallions as in other species, but not in old stallions. In spite of increasing Leydig cells per testis with advancing age (Johnson and Neaves, 1981), the old stallions in the present study lacked the clear first peak. This may be caused by the Leydig cells of old stallions being very active prior to hCG administration in order to maintain the basal testosterone levels. On the other hand, the second peaks were observed in both the middle age and old stallions. This second peak may be related to the long-term effect of hCG on enzyme activation of the steroidgenic pathway (Hall, 1979). The different responses to hCG stimulation between middle age and old stallions should be taken into consideration, when judging testicular function of stallions with secondary hypogonadism. Furthermore, it seems to be rational to evaluate the quantitative response from before injection of hCG to $72 \mathrm{hr}$ after injection when determining the testicular endocrine function of the stallion, since the remarkable peaks could be observed with this period both in middle age and old stallions used in this study.

Our results show clearly a biphasic and prolonged response of serum testosterone to a single hCG injection in stallions. The first testosterone response a short time after hCG administration varied according to age, but the second prolonged response was shown in all stallions regardless of age.

\section{Acknowledgments}

The authors thank to Teikoku Hormone Mfg. Co., Ltd., Japan, for supplying the hCG (Gonatropin); and Dr. Karoline Kretzdorn for reading this manuscript.

\section{References}

Cox JE (1989) Testosterone concentrations in normal and cryptorchid horses. Response to human chorionic gonadotrophin. Anim Reprod Sci 18: 43-50.

Cox JE, Williams JH, Rowe PH, Smith JA (1973) Testosterone in normal, cryptorchid and castrated male horses. Equine Vet J 5: 85-90.

Garnier F, Saez JM (1980) Response of plasma testosterone to human chorionic gonadotropin in the ram. Biol Reprod 22: 832-836.

Graham JM, Desjardins C (1980) Classical conditioning: Induction of luteinizing hormone and testosterone secretion in anticipation of sexual activity. Science, N.Y. 210: 1039-1041.

Hall PF (1979) Gonadotropic regulation of testicular function. In: The Androgens of the Testis (Eik-Nes KB, Dekker M eds.), New York. pp 73-116.

Johnson L, Neaves WB (1981) Age-related changes in the Leydig cell population, seminiferous tubules, and sperm production in stallions. Biol Reprod 24: 
$703-712$.

Kirkpatrick JF, Vail R, Devous S, Schwend S, Baker CB, Wiesner L (1976) Diurnal variation of plasma testosterone in wild stallions. Biol Reprod 15: 98-101.

Makino T (1973) Radioimmunoassay of plasma steroids. Folia Endocr Japon 49: 377-384.

Padron RS, Wischusen J, Hudson B, Burger HG, de Krester DM (1980) Prolonged biphasic response of plasma testosterone to single intramuscular injections of human chorionic gonadotropin. J Clin Endocrinol Metab 50: 1100-1104.

Saez JM, Forest M (1979) Kinetics of human chorionic gonadotropin-induced steroidogenic response of the human testis. I. Plasma testosterone implication for human chorionic gonadotropin stimulation test. J Clin Endocrinol Metab 49: 278-283.

Sharma OP (1976) Diurnal variations of the plasma testosterone in stallions. Biol Reprod 15: 158-162.

Silberzahn P, Zwain I, Guerin P, Benoit E, Jouany JM, Bonnaire Y (1988) Testosterone response to human chorionic gonadotropin injection in the stallion. Equine Vet J 20: 61-63.

Sundby A, Farahat A (1978) Plasma levels of testosterone in bulls: Response to various doses of hCG and PMSG. Acta Endocrinol Copenh 88: 793-800.

Thompson DL, George RLSt, Jones LS, Garza F Jr (1985) Patterns of secretion of luteinizing hormone, follicle stimulating hormone and testosterone in stallions during the summer and winter. $J$ Anim Sci 66: 741-748.

\title{
雄ウマにおけるヒト䄉毛性性腺刺激ホルモン刺激に対する血清テストステロンの反応
}

\author{
奥田＼cjkstart潔·石本 史子・大石 秀夫 ${ }^{1)}$ \\ 前川 則久 ${ }^{2)} \cdot$ 佐藤 邦忠 \\ 帯広畜産大学 $=080$ 帯広市稲田町 \\ 1) 日高地区農共診療センター \\ ${ }^{2)}$ 開業 $\overline{\mathbf{T}} 059-32$ 北海道三石郡三石町字:本桐
}

\begin{abstract}
ウマの非繁殖期（9月）に，3 頭の壮年（ $8 ， 9 ， 10$
歳）および 2 頭の老年（19，25歳）の雄ウマにヒト䋐毛 性性腺刺激ホルモン（hCG）10000国際単位を筋肉内に 一回投与し, 血清中テストステロン濃度の変化を比較し た. hCG 投与の 2 時間後，壮年期のどのウマにも顕著 なテストステロン濃度の上昇が認められたが，老年期の
\end{abstract}

ウマには上昇は認められなかった。しかし，投与後48～ 72時間には年齢に関わらず，すべてのウマに明瞭で急激 な増加が認められた。

以上の結果から, ウマの精巣機能の検査として hCG 負荷試験を実施する際には，年齢による反応性の差を考 虑する必要性が示された。 